\author{
I.Z. Shchur, \\ orcid.org/0000-0001-7346-1463, \\ V.P. Turkovskyi, \\ orcid.org/0000-0001-9456-2394
}

National University "Lviv Polytechnic”, Lviv, Ukraine, e-mail: ihor.z.shchur@lpnu.ua

\title{
INTEGRATED SYSTEM OF MODULAR POWER SUPPLY AND MULTILEVEL CONTROL OF BRUSHLESS DC MOTOR FOR ELECTRIC VEHICLES
}

Purpose. Development of a multi-purpose control algorithm for a cascaded semiconductor inverter to provide a six-step switching of phase voltages of a brushless DC (BLDC) motor, multilevel regulation of voltages magnitude, charge equalization of battery modules in the modes of traction and regenerative braking of electric vehicles (EV), as well as checking the operability of the developed algorithms by computer simulation.

Methodology. To solve these problems, the methods of automatic control theory, elements of the discrete mathematics, and the theory of algorithms are used. The mathematical model of the studied system was implemented by means of the Simulink application, as well as programming in the MATLAB software.

Findings. Algorithms for coordinated control of the six-step switching of the BLDC motor armature winding, multi-level control of the motor voltages with pulse-width modulation at only one level, and energy management in the form of equalization of the battery modules charges have been developed. A computer mathematical model of the proposed EV electric drive system has been created. Performed simulations confirmed the effectiveness of the developed multi-purpose control algorithm.

Originality. Substantiation and solution of the problem of complex increase of energetic and design indicators, as well as reliability of EV power-traction system due to application of an integrated configuration of the modular electric power supply system and multilevel control of the BLDC motor by means of joint multilevel cascade inverter.

Practical value. The use of the developed solutions will increase the service life of electric motor, the reliability of the whole power-traction system, improve their maintainability, expand the layout and loading of the EV chassis, ensure its fire and electrical safety.

Keywords: electric vehicle, brushless DC motor (BLDC), multi-level cascade inverter, modular power supply system, energy management system

Introduction. According to modern trends in sustainable development, humanity is implementing more renewable energy and trying to reduce toxic emissions to the environment as much as possible. These aspirations have led to the rapid and probably irreversible transition to autonomous electric transport. In addition to environmental and energy advantages over cars, electric vehicles have significant benefits in handling and reliability. However, they also have problems primarily related to the limited energy of the onboard power supply systems and the duration of its recovery - charging of electrochemical batteries. These problems generate new tasks to improve onboard power sources and increase energy efficiency in the operation of all other subsystems and devices of electric autonomous vehicles (EAV). First of all, it involves the largest energy consumer - the electric traction drive. Therefore, the task of finding new technical solutions that can increase the energy efficiency of EAV is especially relevant.

Literature review. Technologies for creating EAVs are rapidly evolving in the directions of their various purposes and classes: personal electric vehicles, passenger and truck EAVs, special vehicles of military applications, and others. Considering the size of the EAVs market, their central power-traction systems consisting of interconnected subsystems - the onboard power supply subsystem and the electric drive subsystem - are subject to strict requirements for energy efficiency, reliability, diagnostics, maintainability, and safety. However, these two major subsystems are mostly examined separate from each other [1].

The individual elements for the electric supply are batteries, supercapacitors, and fuel cells which have low voltages (units of Volt). Therefore, to obtain the required voltage of onboard power supply system (DC bus voltage), many of these elements must be connected in series. This complicates the problem of energy management, such as the equalization of voltages or charges. From this point of view, modular cascade converters, which combine low-voltage modules of autonomous power supply, are characterized by significant advantag-

(c) Shchur I.Z., Turkovskyi V.P., 2020 es such as: enabling efficient management, increasing the energy efficiency of the entire power supply system and reducing its total weight [2]. This implementation also increases the service life and significantly reduces the potential danger in the event of an accident. With the use of modular cascade converters, it is possible to regulate voltages and currents of the DC bus, bidirectional power transfer, and charge equalization of individual modules. Recently, many studies have proposed new topologies of modular cascade converters, which are characterized by additional positive qualities. Thus, in the proposed topology in [3], for the regulation of comparatively high voltage of a DC micro-network with small pulses, the socalled interleaved control is applied, which allows increasing the resultant pulse width modulation (PWM) frequency due to the superposition of shifted in time multiple PWM channels of lower frequency. Modular approaches are also promising for the implementation of hybrid power storage systems built on low-voltage batteries as energy sources and supercapacitor (SC) banks as power sources. In hybrid power supply systems, due to the large power of the SCs, it is possible to extend the battery life significantly. At the same time, different topologies of cascade converters are proposed for combining of different modules: distributed SC modules and one common low-voltage battery [4], distributed hybrid SC/battery modules [5]. Such power supply systems are also beginning to be used as the onboard system for EAVs [6].

Similar topologies of kmultilevel cascaded inverters (MCI), which consist of separate modules built on half-bridge or full-bridge circuits of DC-DC converters, are used in electric drives of medium and high voltages (powers). This helps to reduce the inverter losses and use the simpler and cheaper transistors [7]. Since it is advisable to use separate voltage source to power of each module, such drives are organically combined with the same hybrid modules of the EAV power supply subsystem [8, 9]. Moreover, modular cascade converters can be assigned to both subsystems: traction control and energy management of power supplies.

A brushless DC motor (BLDC) with excitation from permanent magnets is widely used for electric drive in various sys- 
tems, from low-power fans to significant power vehicles. This is due to the considerable advantages of this electric drive compared to others: maximum values of the specific power and the specific torque, high reliability, simplicity of design and control [10]. Given these advantages, the BLDC drive is a central system for electric vehicles of various classes, particularly with autonomous power supply [1].

To control the electromagnetic torque and speed of highpower BLDC motor with medium-voltage DC bus, multilevel semiconductor converters including the MCIs are used [11, 12]. Because $\mathrm{d} U / \mathrm{d} t$ on transistors in the MCIs is much lower, the problem of electromagnetic compatibility reduces and currents through the bearings of the electric machine decrease which increases the reliability of the MCIs as well as the BLDC motors.

Unsolved aspects of the problem. In the known works on the MCI control of powerful BLDC drives, to obtain close to the sinusoidal shapes of the output voltage and current, the special multilevel PWM technique are used, in particular with phase and level shifts of the triangular or the saw tooth carrier waveforms at each level [13]. This, in our opinion, is due to a high drive's power and the analogy with drives based on asynchronous and synchronous motors which were used earlier than BLDC. However, this approach involves the use of expensive multi-point sensor of the rotor's angular position (for example, an encoder) with all the problems of its installation and reliability. It also complicates the control of the MCI and the energy management of the battery [14]. Since, for control of the BLDC with trapezoidal electromotive force (EMF), sinusoidal currents are not necessary. The traditional for this case six-step control with simple Hall sensors will significantly simplify implementation, control of a modular cascaded system of power supply, and multilevel control of electric drive [15]. However, since energy efficiency is particularly crucial for EAVs, at first, it is advisable to compare the efficiency of the sinusoidal and the six-step control of permanent magnet motor.

Purpose of the study is the development of a multi-purpose control algorithm for a modular cascaded converter which provides the six-step switching of phase voltages of BLDC motor, multi-level regulation of their magnitude, and charge equalization of the battery modules in traction and regenerative braking modes of EAVs, as well as verification of the developed algorithm by computer simulation. This control algorithm fully realizes the advantages of the modular approach to the onboard power supply system's construction as well as the integrated control of the EAV's electric drive and energy management of the battery by only the MCI.

Methods. Automatic control of the investigated powertraction system is carried out by the control system and is performed directly by the MCI. In the functioning of this system, in addition to the traditional external control of speed and current (torque) of the BLDC, three main control algorithms which have their futures for the MCI are developed consistently: 1) switching of the modules to provide the six-step control of BLDC based on the signals from Hall sensors; 2) voltage regulation following the reference applied to the two phases of the BLDC motor; 3) equalization of charges of the battery modules (algorithm BMS - Battery Management System). The methods of the automatic control theory, elements of the discrete mathematics, and the theory of algorithms are used to solve these problems. The mathematical model of the studied system was implemented using the Simulink as well as programming in the MATLAB environment.

Results. Comparison of energy efficiency of the sinusoidal and the six-step control of BLDC drive. The losses in copper are dominated in BLDC motor. Since their value depends on the method of controlling the armature current, these losses should be compared in the permanent magnet electric machines with sinusoidal and trapezoidal EMF at the same power and powered by $D C$ bus with the same voltage $U_{D C}$.
At the sinusoidal control, the motor phase EMF is equal to

$$
e_{\sin }(t)=E_{0} \sin \left(\frac{2 \pi t}{T}\right)
$$

and the voltage inverter forms the current in this phase armature winding

$$
i_{\mathrm{sin}}(t)=I_{0} \sin \left(\frac{2 \pi t}{T}\right)
$$

where $E_{0}$ and $I_{0}$ are, respectively, the amplitudes of the EMF and the current at the sinusoidal control.

At the six-step control, the EMF and the armature current in the phase winding are respectively

$$
\begin{gathered}
e_{6}(t)= \begin{cases}\frac{12 E_{6} t}{T}, & \text { if } t \leq \frac{T}{12} \\
E_{6}, & \text { if } \frac{T}{12} \leq t \leq \frac{5 T}{12} \\
\frac{12 E_{6} t}{T}+6 \cdot E_{6}, & \text { if } \frac{5 T}{12} \leq t \leq \frac{T}{2}\end{cases} \\
i_{6}(t)= \begin{cases}0, & \text { if } t \leq \frac{T}{12} \\
I_{6}, & \text { if } \frac{T}{12} \leq t \leq \frac{5 T}{12}, \\
0, & \text { if } \frac{5 T}{12} \leq t \leq \frac{T}{2}\end{cases}
\end{gathered}
$$

where $E_{6}$ and $I_{6}$ are, respectively, the amplitudes of the EMF and the current at the six-step control.

Electromagnetic power for a half of the period equals

$$
P=\frac{2}{T} \int_{0}^{T / 2} e(t) \times i(t) d t .
$$

Substituting (1-4) into (5), after integration, we obtain for both control methods respectively

$$
P_{\text {sin }}=\frac{6 E_{0} I_{0}}{\pi^{2}} ; \quad P_{6}=\frac{2 E_{6} I_{6}}{3} .
$$

Given the known correlation between $U_{D C}$ and the maximum amplitudes of the EMF for both control methods, respectively $U_{D C}=\sqrt{3} E_{0}$ and $U_{D C}=2 E_{6}$, at equal values of the electromagnetic power (6), we obtain the following relationship between the currents' amplitudes

$$
I_{6}=\frac{18}{\sqrt{3} \pi^{4}} I_{0}=1.053 I_{0} .
$$

The following equation determines the power loss in the active resistance $R$ of the motor armature winding

$$
\Delta P=\frac{2}{T} \int_{0}^{T / 2} i^{2}(t) R d t .
$$

Substituting the dependences of the currents for two control methods, respectively (2) and (4), in (8) and taking into attention the obtained relationship between amplitudes of the currents (7), it is determined that, to ensure the same power of the motors and them supply from the same voltage of the $D C$ bus, the copper losses in the machine under the six-step control compared to the sinusoidal control will increase by $k$ times, where

$$
k=\frac{\Delta P_{6}}{\Delta P_{\text {sin }}}=\frac{144}{\pi^{4}}=1.478 .
$$

Assuming that the relative power losses in copper at the rated load and the sinusoidal control is 0.1 , the corresponding relative power losses at the six-step control will be 0.1478 . 
Then, we obtain the following difference in the nominal efficiency

$$
\Delta \eta=\eta_{\text {sin }}-\eta_{6}=(1+0.1)^{-1}-(1+0.1478)^{-1}=0.038
$$

The obtained difference in efficiency at the level of $3.8 \%$ is significant. However, the considering higher losses in a voltage inverter at the sinusoidal control and the impact of the losses in steel reduce this difference. Therefore, to significantly simplify control, increase the system reliability, and reduce its cost, it is advisable to use the six-step control for BLDC driven EAVs.

Configuration of the system and its work. The investigated power-traction system (Fig. 1) consists of the BLDC motor which is switched by the modular MCI. The control system has two control loops: the inner current loop with a current regulator CR of the PI structure and the outer angular speed control loop with a speed regulator SR of the P structure. Rotor position signals are generated by the Hall sensors HS1HS3. They come to a commutator $\mathrm{K}$ that performs the function of forming the switching control signals $g_{1}-g_{6}$ for the MCI. The Hall sensor signals are also used to measure the angular speed of the BLDC motor by which a negative feedback for the SR is realized.

The MCI consists of 6 identical power modules, a control system, and a current estimator CE (Fig. 2). Each power module includes the battery with the voltage $U_{B}$ and a full bridge on four transistors with antiparallel diodes (scheme of the Module $i$ is shown in Fig. 2). The feature of this modular structure is obtaining the voltages of different polarity at the output clamps. Also, module structure provides the ability for the current to bypass the battery and the mode of breaking of the circuit. To ensure the required supply voltage and the possibility of its regulation, the modules are connected in series. Discrete switching on and switching off of the series-connected modules and their PWM control are used for motor voltage regulation. This allows us to get the voltage range from $-U_{B} \cdot n$ to $+U_{B} \cdot n$, where $n$ is the number of modules connected in series. In order to reduce switching losses, only one from the series-connected modules is controlled with PWM, and the other modules are switched discretely.

The six-step control of BLDC drive involves the simultaneous current flow through two phases of the motor at each time. The order of switching changes every 60 electrical degrees. For the scheme shown in Fig. 2, a cascade of four modules is connected to the two phases of the motor armature winding. Since current flows through them in one direction, two modules must be connected to the one polarity and two modules - to the opposite polarity. In this case, the number of MCI levels including zero level is determined by the expression $D=4 m+1$, where $m$ is the number of modules connected in series in the circuit of one phase of the motor. In the investigated scheme (Fig. 2), $m=2$. As a result, we obtain the 9-level MCI.

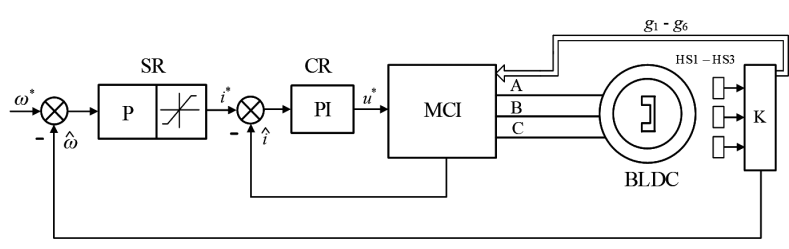

Fig. 1. General structure of investigated power-traction system of $E A V$

The CE is designed to calculate the resulting value of direct current consumed by the BLDC drive from all working batteries in the traction mode (positive value) or given to all working batteries in the regenerative braking mode (negative value). The value of the estimated DC current $\hat{i}$ is used to implement the current feedback to the CR. To determine the resulting value of the BLDC current, we used three current sensors CS1-CS3 in the motor phases and the switching signals from the Hall sensors $g_{1}-g_{6}$.

Algorithm for switching of one power transistor module. Three specified external discrete signals determine the operation of the module: $S D$ gives permission to switch the module; $p$ determines the polarity of the module voltage $(0-$ the positive voltage polarity; 1 - the negative polarity); $b$ is the signal coming from the voltage control subsystem and determines how many modules need to be turned on to provide a reference voltage of the BLDC drive. Table 1 shows all possible combinations of these logic signals that determine the states of the power module's transistors and the mode of module operation. The following logic equations define the transistor control signals $\left(S_{1}-S_{4}\right)$

$$
\begin{gathered}
S_{1}=b \wedge p \wedge S D ; \\
S_{2}=(\bar{b} \wedge \bar{p} \wedge S D) \vee(\bar{b} \wedge p \wedge S D) \vee(b \wedge p \wedge S D) ; \\
S_{3}=b \wedge p \wedge S D ; \\
S_{4}=(\bar{b} \wedge \bar{p} \wedge S D) \vee(\bar{b} \wedge p \wedge S D) \vee(b \wedge \bar{p} \wedge S D) .
\end{gathered}
$$

Based on these logical equations, the switching units for the power transistors of the module are made.

The BLDC switching algorithm generates logic signals $\mathrm{SD}$ and $p$ for modules in each phase of the BLDC motor separately based on signals $g_{1}-g_{6}$ (signals $S D_{A}, S D_{B}, S D_{C}$ and $p_{A}, p_{B}$, $\left.p_{C}\right)$. As a result of the analysis, the following expressions are obtained

$$
\begin{aligned}
& S D_{A}=\left(g_{1} \vee g_{2} \vee \bar{g}_{3} \vee g_{4} \vee g_{5} \vee \bar{g}_{6}\right) \wedge\left(g_{1} \vee g_{2} \vee g_{3} \vee \bar{g}_{4} \vee \bar{g}_{5} \vee g_{6}\right) ; \\
& S D_{B}=\left(g_{1} \vee \bar{g}_{2} \vee g_{3} \vee g_{4} \vee \bar{g}_{5} \vee g_{6}\right) \wedge\left(\bar{g}_{1} \vee g_{2} \vee g_{3} \vee g_{4} \vee g_{5} \vee \bar{g}_{6}\right) ; \\
& S D_{C}=\left(\bar{g}_{1} \vee g_{2} \vee g_{3} \vee \bar{g}_{4} \vee g_{5} \vee g_{6}\right) \wedge\left(g_{1} \vee \bar{g}_{2} \vee \bar{g}_{3} \vee g_{4} \vee g_{5} \vee g_{6}\right) ; \\
& p_{A}=\left(\bar{g}_{1} \vee g_{2} \vee \bar{g}_{3} \vee \bar{g}_{4} \vee g_{5} \vee \bar{g}_{6}\right) \wedge\left(\bar{g}_{1} \vee g_{2} \vee g_{3} \vee \bar{g}_{4} \vee \bar{g}_{5} \vee \bar{g}_{6}\right) ; \\
& p_{B}=\left(g_{1} \vee \bar{g}_{2} \vee \bar{g}_{3} \vee g_{4} \vee \bar{g}_{5} \vee \bar{g}_{6}\right) \wedge\left(\bar{g}_{1} \vee \bar{g}_{2} \vee \bar{g}_{3} \vee g_{4} \vee g_{5} \vee \bar{g}_{6}\right) ; \\
& p_{C}=\left(\bar{g}_{1} \vee \bar{g}_{2} \vee g_{3} \vee \bar{g}_{4} \vee \bar{g}_{5} \vee g_{6}\right) \wedge\left(g_{1} \vee \bar{g}_{2} \vee \bar{g}_{3} \vee \bar{g}_{4} \vee \bar{g}_{5} \vee g_{6}\right) .
\end{aligned}
$$

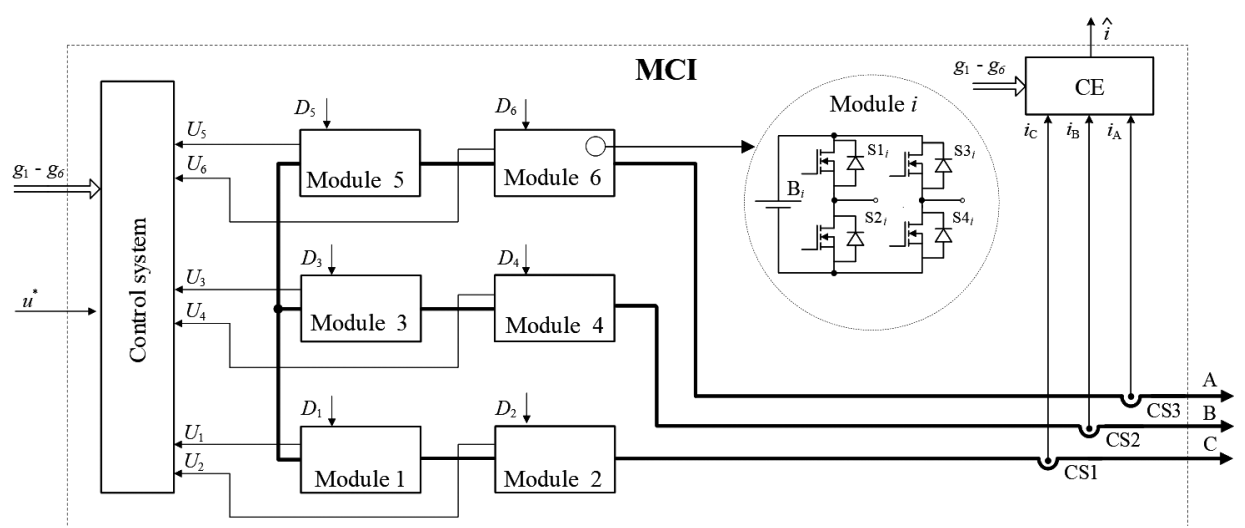

Fig. 2. Scheme of modular multilevel cascaded inverter 
Table 1

The table of truthfulness of the control signals for the power module transistors

\begin{tabular}{|c|c|c|c|c|c|c|c|l|}
\hline No & $b$ & $p$ & $S D$ & $S_{1}$ & $S_{2}$ & $S_{3}$ & $S_{4}$ & Module operation mode \\
\hline 1 & 0 & 0 & 0 & 0 & 0 & 0 & 0 & breaking the circuit \\
\hline 2 & 0 & 0 & 1 & 0 & 1 & 0 & 1 & bypassing the battery \\
\hline 3 & 0 & 1 & 0 & 0 & 0 & 0 & 0 & bypassing the battery \\
\hline 4 & 0 & 1 & 1 & 0 & 1 & 0 & 1 & bypassing the battery \\
\hline 5 & 1 & 0 & 0 & 0 & 0 & 0 & 0 & breaking the circuit \\
\hline 6 & 1 & 0 & 1 & 1 & 0 & 0 & 1 & positive voltage polarity \\
\hline 7 & 1 & 1 & 0 & 0 & 0 & 0 & 0 & breaking the circuit \\
\hline 8 & 1 & 1 & 1 & 0 & 1 & 1 & 0 & negative voltage polarity \\
\hline
\end{tabular}

The voltage control algorithm consists of three identical groups, in which the value of the reference voltage $u^{*}$ is compared with the battery voltage of the module 1 that works with PWM. If the value of $u^{*}$ is greater than the battery voltage of this module, then the module 2 turns on at its full voltage, and the value of the reference voltage is accepted as $u^{*}=\left(u^{*}-U_{B 2}\right)$. Then again, there is a comparison of the new value of the reference voltage with the battery voltage of the module 1 and the turning on of the next module, etc. Finally, under the condition $u^{*}<U_{B 1}$, the ending reference voltage value is converted into the PWM control signal of the module 1: $D_{1}=u^{*} / U_{B 1}$. Based on such comparisons, a task for switching on the required number of modules (signals $b_{2}, b_{3}, b_{4}$ ) and the signal for PWM control $D_{1}\left(b_{1}=1\right)$ are formed. Since the reference signal $u^{*}$ is formed in the current control loop, it may contain oscillations and interference. When the value of $u^{*}$ is close to a multiple of $U_{\mathrm{B}}$, the control system responds to these interferences, which leads to multiple switching of the modules. To reduce these adverse effects, a hysteresis was introduced to turn off of each module.

The BMS algorithm is used to discharge and charge the battery modules evenly. It also provides the even wear of all batteries. In the proposed control system, the equalization of battery charges occurs by estimating their states of charge (SOC) and adjusting according to them batteries discharging or charging levels accordingly. For equal discharging of the battery modules, more power must be consumed from a battery with a higher SOC, and for equal charging - with a lower SOC. At the beginning of the algorithm, the operation mode is determined by the variable 'currentDirection' $(0-$ consumption, 1 - recuperation). Based on the operating mode, the 'sortDirection' parameter is set. It determines the sorting direction according to the SOC levels of the battery modules. This parameter can be set as 'Ascend' - sorting in ascending order and as 'Descend' - sorting in descending order. The estimation of relative power consumption is carried out based on the signals of the reference voltages of the modules $\left(b_{2}, b_{3}, b_{4}\right)$ and the PWM control signal $D_{1}$, which are obtained from the voltage control algorithm. If the module is switched on discretely, its consumed power will be maximum, if the module is switched off, the power consumption is 0 , and if the module works with PWM, its power consumption will be intermediate. To eliminate the permanent redirection of the task signals $b_{1}-$ $b_{4}$, the module batteries SOC values are rounded an integer (as a percentage). Based on the signals of the permission on modules switching $S D_{A}, S D_{B}, S D_{C}$, the selection of modules involved in this switching step is performed. The next step is ranking the SOC data of modules in the direction given by the variable 'sortDirection' and redirection of the switching signals in accordance with modules SOCs and relative power consumption. Adherence to this principle leads to a gradual equalization of batteries charges to the same level.
Algorithm of CE. The current estimator is designed to form the resulting value of current as a superposition of currents in the three phases of BLDC motor. The value of the resulting current directly forms the value of the electromagnetic motor torque. The sign of the resulting current indicates in which mode the electric machine works - in the traction or in the regenerative braking mode. Determination of phase current and its polarity at the output of the CE occurs by operations of discrete mathematics on the switching signals of the six-step voltage inverter. Each switching step will correspond to its value of phase current and its polarity (Table 2). Based on Table 2, a logical expression for the resulting value of the armature current was obtained as

$$
\begin{gathered}
\hat{i}=\left(g_{1} \wedge g_{6}\right) i_{A}+\left(g_{2} \wedge g_{3}\right) i_{B}+\left(g_{4} \wedge g_{5}\right) i_{C}- \\
-\left(g_{2} \wedge g_{5}\right) i_{A}-\left(g_{1} \wedge g_{4}\right) i_{B}-\left(g_{3} \wedge g_{6}\right) i_{C} .
\end{gathered}
$$

Dependence (10) is used to implement the CE model.

System model in MATLAB/Simulink. The parameters of the experimental BLDC drive are presented in Table 3. The MCI model uses blocks from the Simscape/Specialized Power Systems library of the Simulink package. The created MCI model (Fig. 3) consists of the following main parts: Power circuit, BLDC switching system, Voltage regulation system and BMS, Current estimator.

The power circuit consists of 6 transistor modules, each module contains 4 transistors of the MOSFET type. A battery module is connected to each transistor module. The model of battery module is borrowed from Simulink, too. Two modules are connected in cascade. Each cascade is connected to the motor by one clamp and to the common point by the other clamp. The CE is realized using logic blocks and switch blocks according to (10). Using these switches at each moment, the value of the phase current measured by the current sensor transmits to the output of the CE.

The voltage control system and the BMS are represented by two main blocks of the MATLAB function (Fig. 3), which contain programs of operation of these subsystems. These pro-

Table 2

The resulting current value on each switching step

\begin{tabular}{|c|c|c|c|c|c|c|c|}
\hline No & $g_{1}$ & $g_{2}$ & $g_{3}$ & $g_{4}$ & $g_{5}$ & $g_{6}$ & Value of the resulting current \\
\hline 1 & 1 & 0 & 0 & 0 & 0 & 1 & $i_{A}$ \\
\hline 2 & 0 & 1 & 1 & 0 & 0 & 0 & $i_{B}$ \\
\hline 3 & 0 & 0 & 0 & 1 & 1 & 0 & $i_{C}$ \\
\hline 4 & 0 & 1 & 0 & 0 & 1 & 0 & $-i_{A}$ \\
\hline 5 & 1 & 0 & 0 & 1 & 0 & 0 & $-i_{B}$ \\
\hline 6 & 0 & 0 & 1 & 0 & 0 & 1 & $-i_{C}$ \\
\hline
\end{tabular}

Table 3

Parameters of the BLDC drive and the battery module

\begin{tabular}{|l|c|}
\hline \multicolumn{1}{|c|}{ Parameter } & Value \\
\hline Rated power $(\mathrm{kW})$ & 1.2 \\
Rated DC voltage $(\mathrm{V})$ & 170 \\
Rated speed $(\mathrm{rpm})$ & 2000 \\
Rated torque $(\mathrm{Nm})$ & 6.0 \\
Number of pole pairs & 2 \\
Winding resistance $(\Omega)$ & 0.875 \\
Winding inductance $(\mathrm{H})$ & 0.0035 \\
Flux linkage by one pair of permanent magnets $(\mathrm{Wb})$ & 0.175 \\
Moment of inertia $\left(\mathrm{kg} \cdot \mathrm{m}^{2}\right)$ & 0.02 \\
Battery capacity $(\mathrm{Ah})$ & 5.0 \\
Battery module nominal voltage $(\mathrm{V})$ & 60 \\
Rated battery discharge current $(\mathrm{A})$ & 20 \\
Battery ESR $(\Omega)$ & 0.02 \\
\hline
\end{tabular}




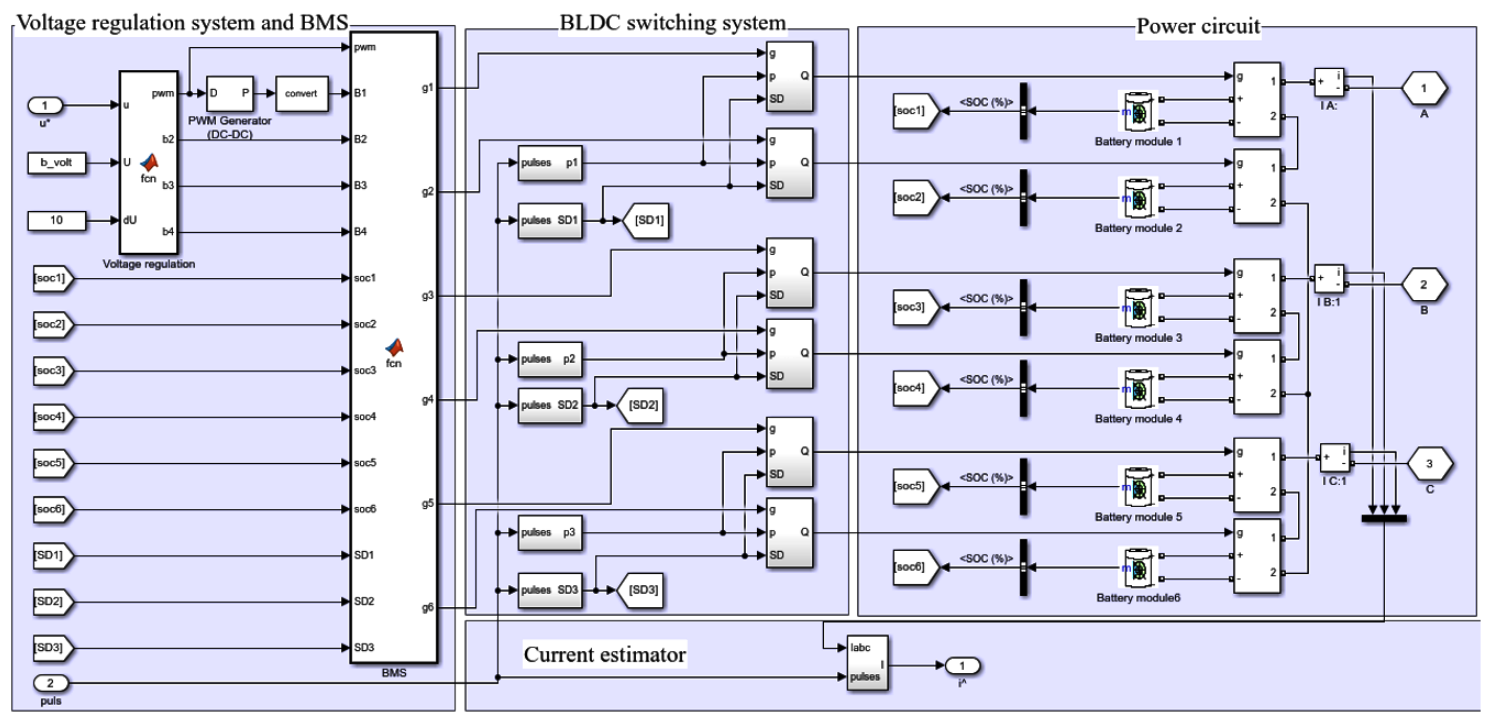

Fig. 3. The MCI model in MATLAB/Simulink

grams are written by MATLAB programming language according to the developed algorithms. The formation of the PWM switching signal of one of the modules is provided by the PWM Generator unit.

Computer simulation results. Computer simulation of the created model was performed for the values of the reference speed and the reference load torque of the BLDC drive which are shown in Figs. 4, $a, b$. The rated speed is set at the initial time. At a time of $0.7 \mathrm{~s}$, the reference speed signal decreases abruptly to half of the rated and at $1.0 \mathrm{~s}-$ up to $25 \%$ of the rated value (Fig. 4, a). The rated load torque is applied in the time interval of $0.5-0.8 \mathrm{~s}$. From $1.3 \mathrm{~s}$, the negative load torque is applied (Fig. 4, $b$ ) that simulates the EAV movement from a slope. The PWM frequency was set of $5000 \mathrm{~Hz}$. The parameters of the regulators obtained on the model experimentally were as follows: for the $C R-K_{p}=10, K_{i}=500$; for the $S R-K_{p}=$ $=2.5$.

The results of computer simulation are shown in Figs. 4, $c-e$. As can be seen from the obtained waveforms, the developed control system works out the perturbation of the reference and the load with good dynamics. The obtained character of the resulting armature current (Fig. 4,e) fully corresponds to the character of the formed electromagnetic torque (Fig. 4, $d$ ).

Fig. 5 shows the waveforms of the main variables of phase A of the motor which were recorded for a period from $0.5 \mathrm{~s}$ to $0.6 \mathrm{~s}$. They show that a switching system forms the armature current (Fig. 5, $b$ ) according to the 120-degree principle of conductivity of transistors in accordance with the maximum values of the trapezoidal EMF (Fig. 5, $a$ ), as it should be for the six-step principle of BLDC control. The waveforms of phase (Fig. 5,c) and linear (Fig. 5, $d$ ) voltages of the armature show how the multilevel voltage control is carried out.

A duty cycle of $12 \mathrm{~s}$ duration is used to simulate the BMS operation and check its efficiency. The duty cycle is divided into three time periods during which different values of the reference speed and the load torque are set (Figs. 6, $a, b$ ). This character of the load will allow evaluating the BMS operation in the consumption and the energy recuperation battery modules modes. To quickly change batteries SOC in a short time of the test period, the battery modules capacity was specifically set low, at the level of $0.2 \mathrm{Ah}$. The initial values of batteries SOCs were set different: Module 1-100\%; Module 2-95\%; Module 3-90 \%; Module 4-85\%; Module 5-80\%; Module $6-75 \%$. The computer simulation was performed for two cases: in the first, the BMS system is turned off; in the second, the BMS system works according to the developed algorithm. The SOC change processes of all six battery modules in these

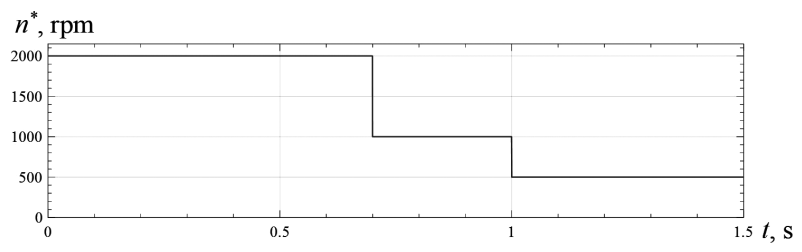

$a$

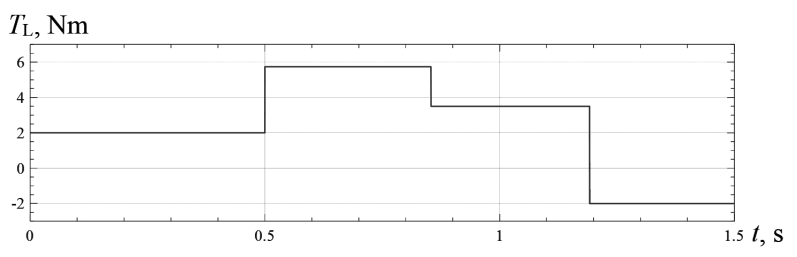

$b$

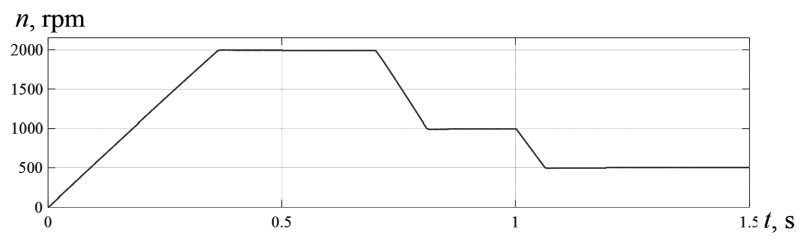

$c$

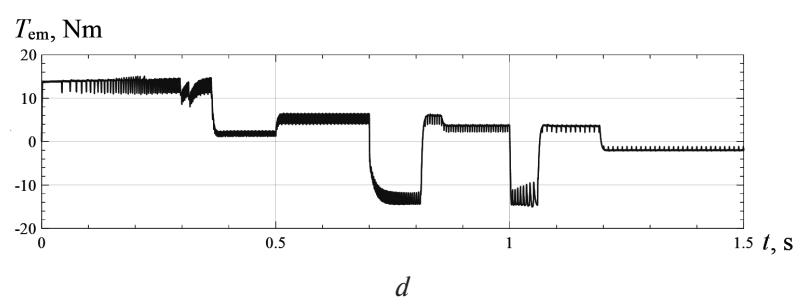

$d$

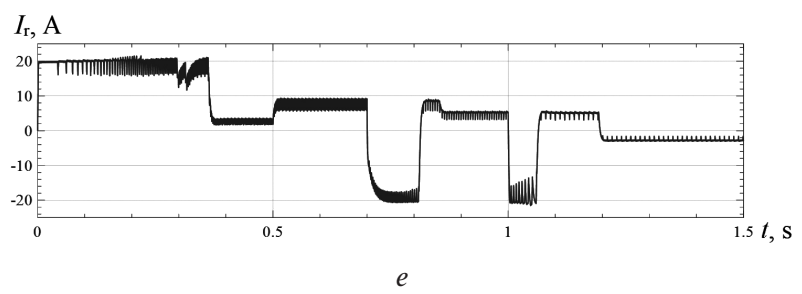

Fig. 4. Waveforms of the variables of the electric drive:

$a$ - reference speed; $b$ - load torque; $c$ - rotor speed; $d$ - electromagnetic torque; $e$ - resulting value of the armature current 

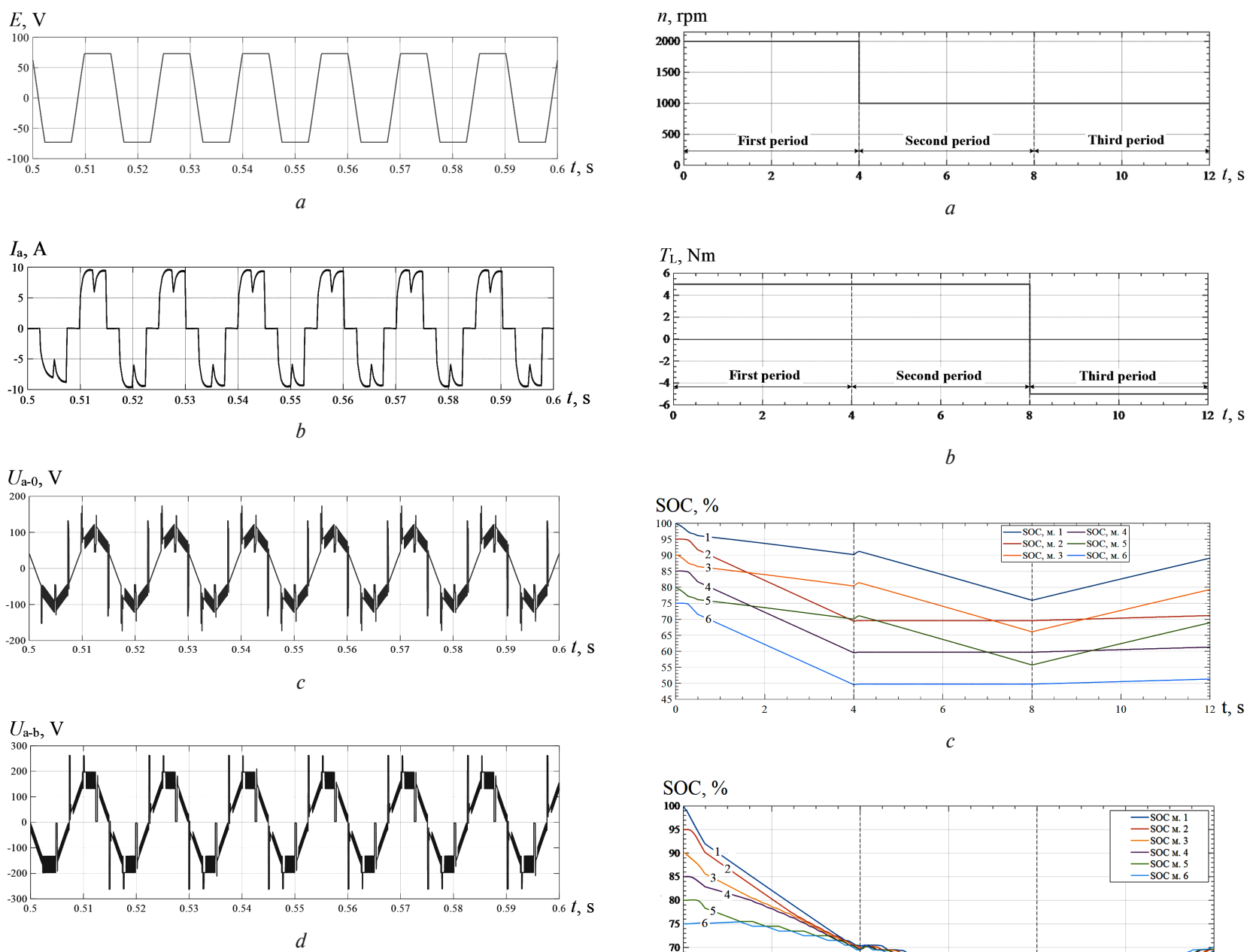

\section{Fig. 5. Waveforms of the variables of phase A for a period from 0.5 to $0.6 \mathrm{~s}$ : \\ $a-E M F ; b-$ current $c$ - phase voltage; $d$ - line voltage}

two cases are shown in Fig. 6, $c$ and Fig. 6, $d$. At absence of the BMS (Fig. 6, c), we can see that, in the first period, more energy is consumed from modules 1,3 , and 5 than from modules 2,4 , and 6 . Even under similar initial conditions, that leads to uneven discharge of the battery modules. After the transition to the second period, the discharge intensity of the modules 1 , 3 , and 5 are saved, but the other modules remain idle. In the third period, energy is recuperated, but even in this case, the modules 2, 4, and 6 remain unused. Using the BMS allows correcting these shortcomings. In Fig. 6, $d$, we can see that there is a gradual equalization of the battery charges of all modules. In the second period, after equalizing the SOCs of all batteries, they are discharging with almost the same intensity and working alternately. Small SOC fluctuations are caused by setting the BMS algorithm to avoid too frequent switching of module modes. In the third period, we observe that energy recovery in the battery also occurs evenly.

\section{Conclusions.}

1. Due to the mass production of EAVs of different classes and purposes, there is a problem of correcting the traditional approaches to separate design of their main subsystems. Therefore, integration of the main subsystems of the EAV power-traction system based on the universal principle of its configuration, construction of interconnections between these subsystems and their control is a promising research direction.

2. The modular approach to construction of the EAV power supply system provides a comprehensive solution of many problems: it increases the noise immunity of the power supply system due to the possibility of shutting down the failed module, improves maintainability which leads to the replacement

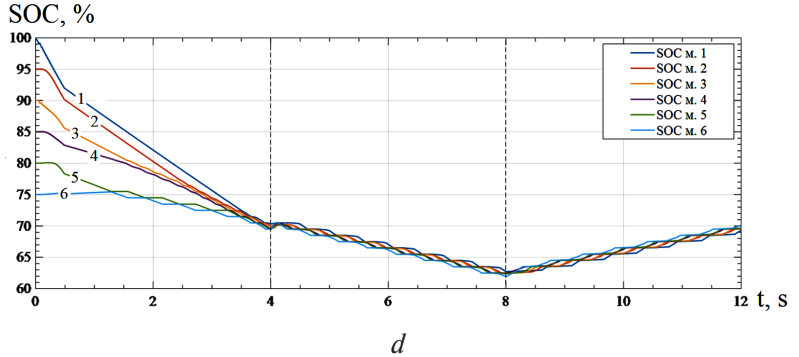

Fig. 6. Waveforms illustrating the BMS operation:

$a$ - reference speed; $b$ - load torque; $c$ - SOCs of 6 battery modules with turned off BMS; $d$-SOCs of 6 battery modules with turned on BMS

of a failed module, expands possibilities of load composition of a EAV chassis thanks to the module spacing options, increases service safety and significantly reduces fire hazard due to the safe voltage of one module.

3. The combination of power supply modules, which is solved by transistor DC-DC converters of cascade topology, extends the modular approach on the power converter with all advantages of expanding control functionality and increasing reliability.

4. The use of multilevel six-step control of the BLDC motor with simple Hall rotor position sensors allows us to implement a simple, reliable, and energy-efficient electric drive system. These advantages are especially important for small EAVs.

5. The developed algorithms for coordinated control of switching of the BLDC armature windings, multilevel regulation of the armature voltage, and charge equalization of the battery modules are simple and can be implemented by cheap microcontrollers, for example, Atmel.

6. The proposed modular approach to the configuration of power-traction systems simplifies the EAV design, unifies components, accelerates design and development of production, increases energy efficiency and reliability.

It is planned to create a mock-up sample of the investigated electric drive system for carrying out an experimental study. 
Acknowledgements. The work was performed within the framework of the research carried out at the expense of the state budget of Ukraine on the topic "Development of a modular integrated approach to the configuration and control of onboard electric drive and power supply systems of autonomous vehicles".

\section{References.}

1. Un-Noor, F., Padmanaban, S., Mihet-Popa, L., Mollah, M., \& Hossain, E. (2017). A comprehensive study of key electric vehicle (EV) components, technologies, challenges, impacts, and future direction of development. Energies, 10(8), 1-82. https://doi.org/10.3390/en10081217.

2. Liang, B. Y., \& Li, Y.S. (2017, Dec. 12-14). A review of DC/DC converter based on MMC. $20177^{\text {th }}$ Int. Conf. on Power Electronics Systems and Applications - Smart Mobility, Power Transfer \& Security (PESA), Hong Kong, China, (pp. 1-6). https://doi.org/10.1109/pesa.2017.8277749.

3. Sun, Z., Qu, D., Wang, M., \& Chen, G. (2015, June 3-5). Study of modular cascaded DC-DC converter with interleaved control for Energy Storage System. 2015 IEEE 24 ${ }^{\text {th }}$ Int. Symp. on Industrial Electronics (ISIE), Buzios, Brazil, (pp. 417-421). https://doi.org/10.1109/isie.2015.7281504.

4. Shchur, I., \& Biletskyi, Y. (2019, Sept. 15-18). Passivitybased control of hybrid energy storage system with common battery and modular multilevel DC-DC converter-based supercapacitor packs. 2019 IEEE $20^{\text {th }}$ Int. Conf. on Computational Problems of Electrical Engineering (CPEE), Lviv-Slavske, Ukraine, (pp. 1-6). https://doi.org/10.1109/cpee47179.2019.8949174.

5. Shchur, I., Kulwas, D., \& Wielgosz, R. (2018, Sept. 10-14). Combination of distributed MPPT and distributed supercapacitor energy storage based on cascaded converter in photovoltaic installation. 2018 IEEE $3^{\text {rd }}$ Int. Conf. on Intelligent Energy and Power Systems (IEPS), Kharkiv, Ukraine, (pp. 139144). https://doi.org/10.1109/ieps.2018.8559513.

6. Stippich, A., van der Broeck, C. H., Sewergin, A., \& Wienhausen, A. H. (2017). Key components of modular propulsion systems for next generation electric vehicles. CPSS Transactions on Power Electronics and Applications, 2(4), 249-258. https://doi.org/10.24295/cpsstpea.2017.00023.

7. Zhou, S., Guan, M., Li, B., Zhou, S., \& Xu, D. (2017, March 26-30). Control of the hybrid modular multilevel converter in motor drive applications. 2017 IEEE Applied Power Electronics Conference and Exposition (APEC), Tampa, FL, USA, (pp. 1-5). https://doi.org/10.1109/apec.2017.7930765. 8. Sau, S., \& Fernandes, B. G. (2017, Oct. 29 - Nov. 11). Modular multilevel converter based variable speed drives with constant capacitor ripple voltage for wide speed range. IECON 2017 - 43 ${ }^{\text {rd }}$ Annual Conference of the IEEE Industrial Electronics Society, Beijing, China, (pp. 1-6). https://doi.org/10.1109/ iecon.2017.8216348.

9. Beshta, O., Khudolii, S., Neuburger, M., \& Neuburger, N. (2019). Control of energy flows in electric drivetrain of electric vehicle with extra DC source. Naukovyi Visnyk Natsionalnoho Hirnychoho Universytetu, (2), 67-71. https://doi.org/10.29202/ nvngu/2019-2/12.

10. Yuniarto, M. N., Rijanto, E., \& Mukhlisin, A. (2019). Design and performance analysis of brushless direct current (BLDC) motor controller for electric scooter. IOP Conf. Series: Materials Science and Engineering, 694, 1-8. https://doi. org/10.1088/1757-899x/694/1/012004.

11. Kalyani, B. S., Mukkavilli, V. M., \& Naik, G. (2017, Jan. 5-7). Performance enhancement of permanent magnet brushless DC motor using multilevel inverter. 2017 IEEE $7^{\text {th }}$ Int. Advance Computing Conf. (IACC), Hyderabad, India, (pp. 472476). https://doi.org/10.1109/iacc.2017.0103.

12. Kumar, P. S., \& Reddy, B. S. S. (2015). A novel topology of cascaded multi-level inverter fed BLDC motor drive. International Journal of Scientific Engineering and Technology, 04(08), 1557-1562. Retrieved from http://ijsetr.com/ uploads/621534IJSETR4383-287.pdf.
13. Al Mashhadany, Y. I. (2015). High-performance multilevel inverter drive of brushless DC motor. International Journal of Sustainable and Green Energy, 4(3-1), 1-7. https://doi. org/10.11648/j.ijrse.s.2015040301.11.

14. Raj, N., G, J., \& George, S. (2016). A modified charge balancing scheme for cascaded H-bridge multilevel inverter. Journal of Power Electronics, 16(6), 2067-2075. https://doi. org/10.6113/jpe.2016.16.6.2067.

15. Shchur, I., \& Turkovskyi, V. (2020, Feb. 25-29). Comparative study of brushless DC motor drives with different configurations of modular multilevel cascaded converters. 2020 IEEE 15 th Int. Conf. on Advanced Trends in Radioelectronics, Telecommunications and Computer Engineering (TCSET), Lviv - Slavske, Ukraine, (pp. 447-451). https://doi. org/10.1109/tcset49122.2020.235473.

\section{Інтегрована система модульного живлення та багаторівневого керування безщітковим двигуном постійного струму для електромобілів}

\section{I. З. Щур, В. П. Турковський}

Національний університет «Львівська політехніка», м. Львів, Україна, e-mail: ihor.z.shchur@lpnu.ua

Мета. Розроблення багатоцільового алгоритму керування каскадним напівпровідниковим інвертором для забезпечення шестикрокової комутації фазних напруг безщіткового двигуна постійного струму (БДПС), багаторівневого регулювання їх величини й вирівнювання зарядів модулів акумуляторних батарей (АКБ) у режимах тяги та рекуперативного гальмування електричних автономних транспортних засобів (ЕАТЗ), а також перевірка роботоздатності розроблених алгоритмів шляхом комп'ютерного симулювання.

Методика. Для вирішення вказаних завдань застосовані методи теорії автоматичного керування, елементи дискретної математики й теорія алгоритмів. Математична модель досліджуваної системи реалізована засобами додатку Simulink, а також програмування в середовищі MATLAB.

Результати. Розроблені узгоджені алгоритми шестикрокової комутації обмотки якоря БДПС, багаторівневого керування напругою якоря двигуна з широтно-імпульсною модуляцією лише на одному рівні та енергетичним менеджментом у вигляді вирівнювання ступеня зарядженості АКБ модулів. Створена комп'ютерна математична модель запропонованої системи електроприводу ЕАТЗ, на якій проведені симулювання, що підтверджують дієвість розроблених алгоритмів багатоцільового керування.

Наукова новизна. Здійснене обгрунтування й розв'язання задачі комплексного підвищення енергетичних, конструкційних показників, а також надійності енергетично-тягової системи ЕАТЗ завдяки застосуванню інтегрованої конфігурації системи модульного електричного живлення й багаторівневого керування БДПС за допомогою спільного багаторівневого каскадного інвертора.

Практична значимість. Використання розроблених рішень дасть змогу підвищити термін служби електричного двигуна, надійність усієї тягово-енергетичної системи, покращить іiі ремонтопридатність, розширить можливості компонування й навантаження кузова транспортного засобу, підвищить його пожежну та електричну безпеку.

Ключові слова: електромобіль, безщітковий двигун постійного струму, багаторівневий каскадний інвертор, модульна система енергетичного живлення, система енергетичного менеджменту 


\section{Интегрированная система модульного питания и многоуровневого управления бесщеточным двигателем постоянного тока для электромобилей}

\section{И. З. Щур, В. П. Турковский}

Национальный университет «Львовская политехника», г. Львов, Украина, e-mail: ihor.z.shchur@lpnu.ua

Цель. Разработка многоцелевого алгоритма управления каскадным полупроводниковым инвертором для обеспечения шестишаговой коммутации фазных напряжений бесщеточного двигателя постоянного тока (БДПТ), многоуровневого регулирования их величины и выравнивания зарядов модулей аккумуляторных батарей (АКБ) в режимах тяги и рекуперативного торможения электрических автономных транспортных средств (ЭАТС), а также проверка работоспособности разработанных алгоритмов путем компьютерного симулирования.

Методика. Для решения указанных задач применены методы теории автоматического управления, элементы дискретной математики и теории алгоритмов. Математическая модель исследуемой системы реализована средствами приложения Simulink, а также программирования в среде MATLAB.

Результаты. Разработаны согласованные алгоритмы шестишаговой коммутации обмотки якоря БДПТ, мно- гоуровневого управления напряжением якоря двигателя с широтно-импульсной модуляцией только на одном уровне и энергетическим менеджментом в виде выравнивания степени заряженности АКБ модулей. Создана компьютерная математическая модель предложенной системы электропривода ЭАТС, на которой проведена симуляция, подтверждающая действенность разработанных алгоритмов многоцелевого управления.

Научная новизна. Осуществлено обоснование и решение задачи комплексного повышения энергетических, конструкционных показателей, а также надежности тягово-энергетической системы ЭАТС благодаря применению интегрированной конфигурации системы модульного электрического питания и многоуровневого управления БДПТ посредством совместного многоуровневого каскадного инвертора.

Практическая значимость. Использование разработанных решений позволит повысить срок службы электродвигателя, надежность всей тягово-энергетической системы, улучшит ее ремонтопригодность, расширит возможности компоновки и нагрузки кузова транспортного средства, обеспечит его пожарную и электрическую безопасность

Ключевые слова: электромобиль, бесщеточный двигатель постоянного тока, многоуровневый каскадный инвертор, модульная система энергетического питания, система энергетического менеджмента

Recommended for publication by O.V.Sadovoi, Doctor of Technical Sciences. The manuscript was submitted 11.05.20. 